\title{
Cikkismertetés: Sporttal az egészség társadalmi egyenlőségéért
}

\author{
Article review: Sports-based recreation as a means to address \\ social inequity in health
}

$\begin{array}{ll}\text { Ismertető: } & \text { Mózes Noémi } \square \\ & \text { Pécsi Tudományegyetem Általános Orvostudományi Kar Orvosi Mikrobiológiai és } \\ & \text { Immunitástani Intézet }\end{array}$

Ismertetett cikk: Elsborg P, Nielsen G, Klinker CD, Melby PS, Christensen JH, Bentsen P. Sports-based recreation as a means to address social inequity in health: why, when, where, who, what, and how. BMC Public Health. 2019 Aug 9;19(1):1084. doi: 10.1186/s12889-019-7428-3

Beküldve: $\quad$ 2019.11. 08.

doi: $\quad$ 10.24365/ef.v61i1.532

\begin{abstract}
Kulcsszavak: egészség; alacsony társadalmi-gazdasági státusz; nem fertőző betegségek; szociális egészségegyenlőtlenség; fiatalok

Keywords: health; low socioeconomic status; noncommunicable diseases; social inequity in health; youth
\end{abstract}

A nem fertőző betegségek, mint a cukorbetegség, a daganatos-, a szív- és érrendszeri, valamint a krónikus légúti megbetegedések jelentős és egyre növekvő népegészségügyi kihívást jelentenek mind a magas, mind a közepes, mind pedig az alacsony jövedelmú országokban. Az alacsony társadalmigazdasági státuszba tartozók élettartama nemcsak alacsonyabb, mint a magasabb jövedelemmel rendelkezők csoportjába tartozó egyéneké, de nagyobb eséllyel szenvednek majd életük során megelőzhető betegségektől is.

A cikk szerzői nem csupán az egészségegyenlőtlenségekkel foglalkoznak, hanem azok determinánsaival, amelyek a mentális, a szociális és a fizikai egészséget is befolyásolják a társadalmi-gazdasági szempontból hátrányos helyzetű lakóhelyeken, illetve azon településrészeken, ahol az ott élők jövedelme és iskolai végzettsége alacsony. Az egészségegyenlőtlenség tényezőinek felismerésével és javításával csökkenthető lenne a társadalmi szakadék, ezért ennek érdekében megelőző intézkedéseket, beavatkozásokat kell eszközölni. A nem fertőző betegségek kialakulását csökkenti a mentális egészségi állapot javítása, valamint a fizikai aktivitás növelése. A cikk szerzőinek elsődleges célja, hogy a hátrányos helyzetű csoportok körében a társadalmi alapú egészségegyenlőtlenségeket csökkentsék. Háromféle egészségfejlesztési megközelítést (életút, színtér, hátrányos helyzetû csoport) kombinálva próbálnak megoldást találni a fizikai aktivitás növelésére.

\section{MIKOR, HOL ÉS KI?}

Ebben a részben a szerzők három egészségfejlesztési megközelítést mutatnak be, amelyek együtt rávilágítanak arra, hogy mikor fontos az egyén életébe beavatkozni, hol a leghatékonyabbak a beavatkozások, valamint kiknek kell alkotniuk 
a célcsoportot, ha a cél a társadalmi egyenlőtlenségek csökkentése.

Kimutatták, hogy a nem fertőző betegségek kialakulásának esélye az ember életciklusa során kumulálódik. A kutatások azt is felfedték, hogy a fizikai aktivitás csökkenti a krónikus betegségek kockázati tényezőit, például a 2. típusú cukorbetegség, valamint a szív- és érrendszeri betegségek esetében. Az alacsony jövedelmú csoportok hajlamosabbak a fizikai inaktivitásra, ami életmódkockázatot jelent, vagyis egész életük során fennálló kumulatív kockázati tényező, ezért az életútmegközelítés célja a beavatkozások minél korábbi életszakaszban való végrehajtása.

Megállapították, hogy az egészségre nemcsak a gyermek életének első 1000 napja, de a következő 7000 nap is (kb. 22 éves kor) nagy hatással van.
Ez azt jelenti, hogy a terhesség, a csecsemő- és gyermekkor, illetve az iskolai egészségfejlesztés és az ifjúsági közösségi programok is fontos szerepet játszanak a primer prevenció során. Tehát a preventív szemlélet kialakítását minél előbb, már kora gyermekkorban el kell kezdeni, hiszen akkor a fiatalokat könnyebb rávenni játékos formában a sportolásra, vagy megtanítani nekik az egészséges táplálkozás alapjait. Sporttal töltött szabadidőnek tekintendő minden olyan tevékenység, amely magában foglal egy vagy több típusú sport ihlette fizikai aktivitást.

A színtéralapú megközelítés esetében az intervenciók során figyelembe kell venni a környezetet, amely önmagában lényeges befolyásoló tényező főleg a fiatal, hátrányos helyzetű célcsoportnál.

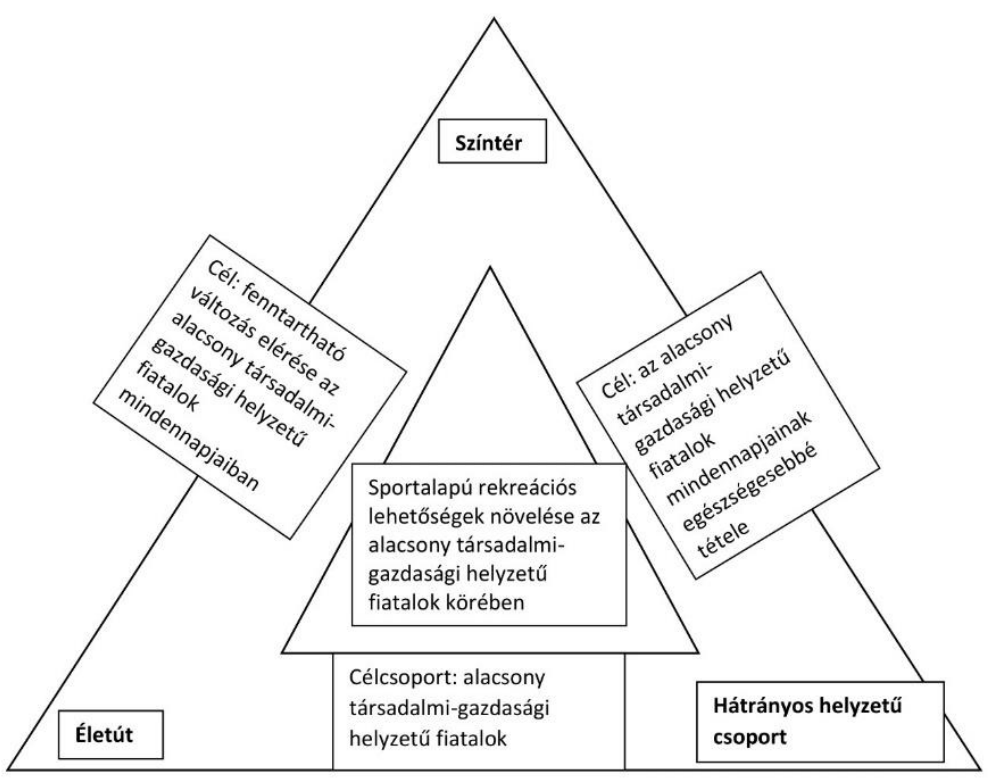

\section{MIT?}

Amikor a sportot, mint a kikapcsolódás fő formáját próbálják beépíteni a hátrányos helyzetű lakosság mindennapjaiba, akkor az alapvető megközelítés a fenntartható részvétel. Ennek érdekében fontos figyelembe venni, hogy a fizikai aktivitás melyik formája adaptálható, illetve melyikkel lehet a legnagyobb egészségnyereséget elérni az adott lakosság körében. Sok kísérleti tanulmány vizsgálta a fizikai aktivitás hatását a testi egészségre. Ezen kutatások elsősorban az egyéni hatásokra koncentráltak, például arra, hogy a futópadon futás, a szobakerékpáron biciklizés milyen pozitív hatással voltak a fizikai egészségre. Ez azonban nem jelenti azt, hogy az egyéni mozgásformák a legegészségesebek. A csoportos testmozgás, legyen akár tánc vagy egyesületben sportolás, fokozza a mentális jóllétet. A kutatók arra a következtetésre jutottak, hogy a részvétel társasági jellege miatt a klub- vagy csapatalapú sporttevékenységek jobb eredményeket mutatnak, mint az egyéni sporttevékenységek. 
Ezen felül kimutatták, hogy a csoportos mozgás további előnyöket is tartogat az egyén és a társadalom számára, például készségek fejlesztése, rizikómagatartás csökkenése, jobb iskolai teljesítmény és búnmegelőzés.

\section{HOGYAN?}

A sikeres beavatkozás érdekében a szerzők a következőket javasolják:

1. A sportalapú tevékenységek legyenek ingyenesek a beavatkozás során.

A hátrányos helyzetû csoportok esetében a programokban részvétel legnagyobb akadálya az, hogy a sportklubok dijai sokszor megfizethetetlenek számukra. A szerzők emiatt javasolják, hogy az egyes sporttevékenységek és a sportklubtagság ingyenes vagy kedvező árú legyen a gyermekek és az alacsony jövedelmú családok fiataljai részére.

2. A sportalapú tevékenységek kevés létesítménnyel vagy létesítmények nélkül is legyen elérhető.

Az épített környezet fontos szerepet játszik a hátrányos helyzetú gyermekek és fiatalok körében, hiszen költségmentes lehetőséget kínálhat sportolásra a lakóhely közelében. Például a nyilvános parkok lehetőséget adnak szervezett és informális, nem strukturált tevékenységek végzésére. Tanulmányok szerint a fiatalok legnagyobb számban a sportpályával rendelkező parkokat használják, mivel azok nyilvánosak, ingyenesek és folyamatosan rendelkezésre állnak. Ezen sportpályákkal ellátott parkok elérhetősége különösen fontos az alacsony társadalmi-gazdasági helyzetû családokból szár- mazó gyermekek és fiatalok számára, mivel ők alulreprezentáltak a sportklubok foglalkozásain.

3. A sportalapú tevékenységek legyenek helyben elérhetőek a gyermekek és a fiatalok számára.

Az alacsony társadalmi-gazdasági státuszú gyermekek és fiatalok kevesebb szervezett sporteseményen vesznek részt. Ezért fontos szempont, hogy a sportprogramokat a település olyan részén kell elhelyezni, ahol mindenki számára könnyen hozzáférhetők, megközelíthetők.

A szervezett, sportalapú kikapcsolódás, amely kihasználja a létesítményeket a szegényebb területeken olyan új szemlélethez is vezethet, amely a fizikai aktivitás többféle módját teszi lehetővé, például helyi zöldterületek vagy új létesítmények használatának bevonásával. A lehetőségeknek csak a képzelet szab határt, hisz az elérhetőségektől függően be lehet vonni hétköznapi eszközöket is a sporttevékenységek során. Például fákat, bokrokat, tartályokat használhatnak focipálya kialakításához, vagy éppen egy parkoló is felhasználható, hogy táncórát tartsanak.

\section{A sportalapú tevékenységeket alakítsák a célcsoporthoz.}

Mivel a fizikai aktivitás gyakran háttérbe szorul, ezért fontos vonzóvá tenni azt a lakosság számára. Amikor megpróbálnak egy programot a helyi szokásokhoz igazítani, kulcsfontosságú a helyben lakók igényét felmérni, és tanácsukat kikérni. A tevékenységek testre szabása a fiatalok számára magában foglalja a kedvelt mozgásformák azonosítását, a célcsoport életkorának megfelelő tevékenységek fejlesztését, a biztonságos környezet megteremtését a gyermekek és fiatalok számára, ez által sikerül a szülők bizalmát és támogatását is elérni.

\section{TANULSÁGOK A HAZAI SZAKEMBEREK SZÁMÁRA}

Hazánkban is fontos lenne az egészségfejlesztési projektek megkezdése előtt a fenti cikkben olvasható szempontok figyelembevétele. A munkatervek kidolgozásakor a helyi környezet és a célpopuláció igényeinek felmérése alapvető ahhoz, hogy mindenki számára elérhető programokat tudjanak szervezni, így lehetőség nyílna a társadalmi különbség csökkentésére. 